\title{
Expansion of invasive Ceratium furcoides (Dinophyta) toward north-central Brazil: new records in tropical environments
}

\author{
Avanço da invasão de sistemas aquáticos por Ceratium furcoides (Dinophyta) em direção
} ao centro-norte brasileiro: novos registros em ambiente tropicais

Weliton José da Silva ${ }^{*}$, Ina de Souza Nogueira² ${ }^{2}$ Enaide Marinho de Melo-Magalhães ${ }^{3}$, Sarah Haysa Mota Benício ${ }^{2}$, Sheila Magalhães Pessoa ${ }^{2}$ and Mariângela Menezes ${ }^{4}$

${ }^{1}$ Laboratório de Microalgas Continentais - LAMiC, Departamento de Biologia Animal e Vegetal, Centro de Ciências Biológicas, Universidade Estadual de Londrina - UEL, Rodovia Celso Garcia Cid, Pr 445, Km 380, Campus Universitário, CP 10.011, CEP 86057-970, Londrina, PR, Brasil

${ }^{2}$ Laboratório de Análise e Gerenciamento Ambiental de Recursos Hídricos - LAMARH, Instituto de Ciências Biológicas, Universidade Federal de Goiás - UFG, Campus Samambaia, Alameda Palmeiras, Quadra I, Lote i2, CEP 74690-900, Goiânia, GO, Brasil

${ }^{3}$ Laboratórios Integrados de Ciências do Mar e Naturais, Instituto de Ciências Biológicas e da Saúde, Universidade Federal de Alagoas - UFAL, Av. Aristeu de Andrade, 452-Farol, CEP 57021-090, Maceió, AL, Brasil

${ }^{4}$ Laboratório de Ficologia - LabFico, Departamento de Botânica, Universidade Federal do Rio de Janeiro - UFRJ, Museu Nacional, Quinta da Boa Vista, s/n, São Cristovão, CEP 20940-040, Rio de Janeiro, RJ, Brasil

* e-mail: welitondasilva@yahoo.com.br

Cite as: da Silva, W.J. et al. Expansion of invasive Ceratium furcoides (Dinophyta) toward northcentral Brazil: new records in tropical environments. Acta Limnologica Brasiliensia, 2018, vol. 30, e210.

Abstract: Aim: We record new occurrences of the invasive species Ceratium furcoides in reservoirs and their affluents in the Paraná River basin, State of Goiás (GO), central-western Brazil, and in some localities in the São Francisco River basin, northeastern region. Methods: Qualitative and quantitative phytoplankton samples were collected from Corumbá Reservoir and Cascatinha Falls, Caldas Novas, GO, and João Leite Reservoir, Goiânia, GO, both in the Paraná River basin, and samples from the São Franscisco River basin. Specimens of $C$. furcoides were observed with optical, epifluorescence and scanning electron microscopy. Results: The individuals of $C$. furcoides from these environments agreed morphologically with populations in other reservoirs in Brazil and other locations, especially concerning the tabulation and the shape of the fourth apical plate. These environments ranged from oligotrophic to eutrophic conditions. Physical and chemical variables of these waterbodies, compared to other environments where this species was found, demonstrate that $C$. furcoides is a highly eurytopic species. The dispersal pattern of $C$. furcoides seems to be more complex than upstream-downstream regulation, since the species occurs in high-altitude environments and systems upstream from previously recorded locations. Conclusion: An analysis based on the areas of occurrence and the chronology of the records demonstrated that $C$. furcoides has spread toward northern Brazil. Studies of the relationships among populations recorded in other parts of Brazil and South America are required in order to develop accurate models of dispersal for this invasive species, and will facilitate the development of management policies for aquatic systems in Brazil.

Keywords: invasive species; São Francisco River basin; Corumbá Reservoir; João Leite Reservoir; central-western Brazil; dinoflagellate. 
Resumo: Objetivo: $\mathrm{O}$ estudo tem como objetivo o registro de ocorrência de $C$. furcoides em reservatórios das bacias do rio Paraná e seus afluentes no estado de Goiás, Centro-oeste brasileiro, e em algumas localidades da Bacia do rio Sáo Francisco, região Nordeste. Métodos: Amostras fitoplanctônicas qualitativas e quantitativas do Reservatório de Corumbá e Cascatinha, Caldas Novas, GO, e Reservatório João Leite, Goiânia, GO, ambos da bacia do rio Paraná foram coletados. Representantes de Ceratium furcoides foram observados em microscopia óptica, de epifluorescência e de eletrônica de varredura. Resultados: Os indivíduos de C. furcoides observados nesses ambientes concordaram morfologicamente com aqueles de outras populaçôes encontradas em outros reservatórios do Brasil e outras localidades, especialmente com relação à tabulação e ao formato da quarta placa apical. Esses ambientes variaram de condiçóes oligotróficas a eutróficas. Variáveis físicas e químicas desses ambientes, comparada com outros sistemas onde essa espécie foi registrada, demonstraram que as condiçôes ótimas para o desenvolvimento de $C$. furcoides são ainda ambíguas para essa espécie. O padrão dispersivo de $C$. furcoides parece ser mais complexo do que aquele regulado pelo sentido montante-jusante, já que a espécie já foi registrada em ambientes de grandes altitudes e à montante de locais previamente registrados. Conclusão: Uma análise com base nas regióes de ocorrência e na cronologia dos registros demonstrou que C. furcoides tem avançado em direçáo ao norte do Brasil. Estudos que forneçam uma melhor compreensão das relaçóes entre as populaçóes registradas no Brasil e em outras partes da América do Sul são requeridos a fim de traçar modelos de dispersão acurados para essa espécie, os quais facilitaráo políticas de gerenciamento para os ambientes aquáticos no Brasil.

Palavras-chave: espécies invasoras; bacia do rio São Francisco; bacia do rio Corumbá; Centro-Oeste brasileiro; dinoflagelado.

\section{Introduction}

An invasive species is defined as a "non-native species that, once established, can spread and rapidly dominate over native species" (Kernan, 2015). The establishment of an invasive species can be directly or indirectly associated with an anthropogenic event, and its dominance can generate negative effects on the biotic community and environment (Alpert et al., 2000; Kernan, 2015). These effects may result in profound ecological, evolutionary and economic impacts (Epanchin-Niell \& Wilen, 2012; Kernan, 2015). Consequently, means of controlling biological invasions are important for ecosystem health. Rapid detection of invasive species and mapping areas with a potential risk of invasions are some of the main strategies for controlling invasions (Lennox et al., 2015; Mazzamuto et al., 2016).

Members of the genus Ceratium Schrank have invaded continental aquatic systems worldwide (Meichtry de Zaburlín et al., 2016). This genus of phytoplanktonic dinoflagellates occurs exclusively in freshwater environments (Gómez et al., 2010), such as in stratified lakes with low nutrient concentrations (Grigorszky et al., 2003). The genus is characterized by thecae composed of four apical (4'), six pre-cingular (6”), six cingular (6c), six post-cingular (6"') and two antapical (2"') plates plus 2 or more sulcal platelets (Gómez et al., 2010).

Currently, Ceratium encompasses about 10 species (Guiry \& Guiry, 2016), of which C. hirundinella (O.F.Müller) Dujardin and C. furcoides (Levander) Langhans are the most common. In $C$. hirundinella all four apical plates reach the apex of the epitheca, whereas in C. furcoides only three apical plates reach this point (Hickel, 1988; Calado \& Larsen, 1997).

Ceratium furcoides was first described as C. hirundinella var. furcoides Levander, based on phytoplankton material from Finland, and later raised to species level by Langhans (1925). The species is common in temperate regions in European countries (Dokulil \& Teubner, 2003), but is also reported as an invasive species in other temperate, subtropical and tropical areas around the world. Ceratium furcoides is currently known from systems in Egypt (El-Otify et al., 2003) and Turkey (Çelekli et al., 2007), China (Chu et al., 2008), India (Khondker et al., 2009; Keshri et al., 2013), Iran (Darki, 2014), Korea (Li et al., 2015) and Taiwan (Wu \& Chou, 1998), Australia (Ling \& Tyler, 2000) and New Zealand (Thomasson, 1974; Jolly \& Chapman, 1977; Cassie, 1978; Simmonds et al., 2015). In American continent, this species it was found in Argentina (Mac Donagh et al., 2005; Daga \& Pierotto, 2014; Meichtry de Zaburlin et al., 2014; Salusso \& Moraña, 2014, 2015), Bolivia (Morales, 2016),, Canada (Dermott et al.,2007) Chile (D. Soto and G. Lembeye, unpublished data; Caputo Galarce et al., 2013; Almanza et al., 2016), Colombia (Ramirez-R et al., 2005; Gil et al., 2012; Villabona-González et al., 2014), Cuba (Comas 2009), Paraguay (Meichtry de Zaburlín et al., 2013), Philippines (Rott et al., 2008; Papa \& Mamaril Sr., 2011), Uruguay (Meichtry de Zaburlín et al., 2016, Bordet et al., 2017) and the USA (Daily, 1960). 
Species of Ceratium were not observed in Brazilian freshwater systems before this century (Cavalcante et al., 2013). In 2007, Santos-Wisniewski et al. (2007) and Silva et al. (2012) recorded C. furcoides in the Rio Grande basin, State of Minas Gerais, in March and December, respectively. In 2008, C. furcoides was also found in Billings Reservoir, State of São Paulo (Matsumura-Tundisi et al., 2010). Oliveira et al. (2011) recorded C. furcoides in reservoirs in the states of Alagoas, Bahia, Pernambuco and Sergipe in April 2009, and Nishimura et al. (2015) found this species in Billings Reservoir and Guarapiranga Reservoir, São Paulo, in September 2009. In 2010, Moreira et al. (2015) observed C. furcoides in a temporary lagoon at high altitude in Minas Gerais.

In 2011, Rosini et al. (2016) recorded C. furcoides in Ilha Solteira Reservoir, São Paulo and Cavalcante et al. (2017) observed this species in aquatic systems from Paraná, and in 2012 this species was observed in several waterbodies in the states of Paraná and Rio Grande do Sul (Cavalcante et al., 2013, 2016; Cassol et al., 2014, 2017; Jati et al., 2014). In 2013, Bressane et al. (2013) and Hackbart et al. (2015) recorded it in Barranco Alto, Minas Gerais, and in Jaguari and Jacareí reservoirs, São Paulo, respectively. In 2014, Oliveira et al. (2016) recorded C. furcoides in Jucazinho and Toritama reservoirs, Pernambuco, Jati et al. (2017) observed it in Paraná, and Crossetti et al. (2018) noted the presence of this species in Garças Reservoir, São Paulo. Ferreira \& Azevedo (2017) recorded C. furcoides in Água Azul lagoon, Guarulhos São Paulo, in 2015. In 2016, Campanelli et al. (2017) reported it from a fish-farm lake in São Carlos, São Paulo, and Almeida et al. (2016) observed it in Maestra Reservoir, Caxias do Sul, Rio Grande do Sul, as previously recorded by Cavalcante et al. (2016, see above). Thus, C. furcoides has been found in Brazilian subtropical and tropical environments, including in high-altitude systems.

The establishment and rapid development of invasive species such as $C$. furcoides in aquatic systems can affect the native communities and the water quality, producing various colors and unpleasant tastes and odors (Berthon, 2015; Meichtry de Zaburlín et al., 2016; Napiórkowska-Krzebietke et al., 2017).Species of this genus have been associated to fish-kill in temperate lakes because the oxygen depletion caused by blooms (Nicholls et al., 1980). Therefore, records of the occurrence of $C$. furcoides are important to provide information about its distribution, dispersion patterns, and contributing to the management of Brazilian aquatic systems.

We here record the occurrence of $C$. furcoides in reservoirs in the Paraná River basin and its sources in Goiás, central-western Brazil, and in some localities of the Sáo Francisco River basin, northeastern Brazil.

\section{Material and Methods}

Cascatinha Falls is located in the eastern area of the Serra de Caldas State Park (PESCaN), a preserved area near Caldas Novas, Goiás, at $750 \mathrm{~m}$ a.s.l. Its waters flow along Saia Velha Stream, Caldas Stream and Pirapitinga River until they enter the north end of the Corumbá Reservoir (1744'53.23”S; 48³3'38.77”W) (Ramos \& Carneiro, 2010). Corumbá Reservoir is located $30 \mathrm{~km}$ from Caldas Novas, at $668 \mathrm{~m}$ a.s.l. The reservoir has an area of $65 \mathrm{~km}^{2}$ and a total volume of $1.5 \mathrm{~km}^{3}$, and was formed by damming the Corumbá River in the Paraná Hydrographic Region (Furnas, 2015).

The João Leite Reservoir is located close to Goiânia, at $730 \mathrm{~m}$ a.s.l., and was formed by damming João Leite Stream (16 $33^{\prime} 55.16^{\prime \prime}$; $\left.49^{\circ} 12^{\prime} 39.66^{\prime \prime} \mathrm{W}\right)$. The reservoir has an area of $10.4 \mathrm{~km}^{2}$ and supplies drinking water to about 2 million inhabitants of the Metropolitan Region of Goiânia (Gusmão \& Valsecchi, 2009).

The São Francisco River is the main aquatic system of the São Francisco Hydrographic Region. It is the longest Brazilian river, reaching 2,914 km from its sourse in the Canastra Mountain Range, State of Minas Gerais, to its mouth in the Atlantic Ocean on the border of the states of Alagoas and Sergipe. Along its course, the river is dammed five times, forming the reservoirs Três Marias, Sobradinho, Luiz Gonzaga, Paulo Afonso and Xingó (Brasil, 2006).

Qualitative samples were taken at Cascatinha Falls, Corumbá Reservoir, and at ten points in the São Francisco River, using a plankton net of $25 \mu \mathrm{m}$ mesh (Table 1). The samples were fixed with Transeau's solution (Bicudo \& Menezes, 2006) and deposited in the Herbarium of the Federal University of Goiás and the Herbarium of the State University of Londrina, respectively (Table 1). Quantitative samples were composed of $100 \mathrm{~mL}$ of water collected from the subsurface at each site described in Table 1, except Cascatinha Falls (GO-Casc) and the margin of the Corumbá Reservoir (GO-Cor-MARG). These samples were 
Table 1. Sites of occurrence of Ceratium furcoides and sample codes.

\begin{tabular}{|c|c|c|c|c|}
\hline Sample Code & Description & $\begin{array}{l}\text { Altitude } \\
\text { (m a.s.I.) }\end{array}$ & Coordinates & $\begin{array}{c}\text { Herbarium } \\
\text { number }\end{array}$ \\
\hline GO-Cor-MID & $\begin{array}{l}\text { GOIÁS, Caldas Novas, Corumbá Reservoir, middle, } \\
\text { lentic, } 10.05 .2015^{1}\end{array}$ & 750 & $\begin{array}{l}17^{\circ} 47^{\prime} 36.70^{\prime \prime} \mathrm{S} ; \\
48^{\circ} 32^{\prime} 32.17^{\prime \prime} \mathrm{W}\end{array}$ & UFG 49802 \\
\hline GO-Cor-MARG & $\begin{array}{l}\text { GOIÁS, Caldas Novas, Corumbá Reservoir, margin, } \\
\text { lentic, } 10.05 .2015^{1}\end{array}$ & 668 & $\begin{array}{l}17^{\circ} 46^{\prime} 39.32^{\prime \prime S} \\
48^{\circ} 34^{\prime} 12.02^{\prime \prime} \mathrm{W}\end{array}$ & UFG 49804 \\
\hline GO-Casc & $\begin{array}{l}\text { GOIÁS, Caldas Novas, Cascatinha, lotic, } \\
10.05 .2018^{1}\end{array}$ & 668 & $\begin{array}{l}17^{\circ} 46^{\prime} 13.83^{\prime \prime S} \\
48^{\circ} 39^{\prime} 29.21^{\prime \prime} \mathrm{W}\end{array}$ & UFG 49801 \\
\hline GO-JL-15/03 & $\begin{array}{l}\text { GOIÁS, Goiânia, João Leite Stream, João Leite } \\
\text { Reservoir, catchment, lentic, 15.03.2016² }\end{array}$ & 730 & $\begin{array}{l}16^{\circ} 33^{\prime} 55.16^{\prime \prime} \mathrm{S} \\
49^{\circ} 12^{\prime} 39.66^{\prime \prime} \mathrm{W}\end{array}$ & - \\
\hline GO-JL-24/05 & $\begin{array}{l}\text { GOIÁS, Goiânia, João Leite Stream, João Leite } \\
\text { Reservoir, catchment, lentic, 24.05.2016² }\end{array}$ & 730 & $\begin{array}{l}16^{\circ} 33^{\prime} 55.16^{\prime \prime} \mathrm{S} \\
49^{\circ} 12^{\prime} 39.66^{\prime \prime} \mathrm{W}\end{array}$ & - \\
\hline AL1-06/05 & $\begin{array}{l}\text { ALAGOAS, Delmiro Gouveia, São Francisco River, } \\
\text { between dam I, II, III and dam IV of Paulo Afonso } \\
\text { Reservoir, downstream, lotic, } 06.05 .2015^{3}\end{array}$ & 167 & $\begin{array}{l}\text { 9²4'36.37"S; } \\
38^{\circ} 12^{\prime} 13.52 " \mathrm{~W}\end{array}$ & $\begin{array}{l}\text { FUEL } \\
58037\end{array}$ \\
\hline AL2-06/05 & $\begin{array}{l}\text { ALAGOAS, Delmiro Gouveia, Xingó Reservoir, } \\
\text { gorge, upstream of Sal River, lentic, 06.05.2015³ }\end{array}$ & 149 & $\begin{array}{l}9^{\circ} 25^{\prime} 58.00 " S \\
38^{\circ} 10^{\prime} 09.08^{\prime \prime} \mathrm{W}\end{array}$ & $\begin{array}{l}\text { FUEL } \\
58038\end{array}$ \\
\hline AL3-06/05 & $\begin{array}{l}\text { ALAGOAS, Delmiro Gouveia, Xingó Reservoir, } \\
\text { downstream from Sal River, upstream from curve of } \\
\text { gorge, from left margin, lentic, } 06.05 .2015^{3}\end{array}$ & 144 & $\begin{array}{l}\text { 9²6'25.10"S; } \\
38^{\circ} 07^{\prime} 18.12 " \mathrm{~W}\end{array}$ & $\begin{array}{l}\text { FUEL } \\
58039\end{array}$ \\
\hline AL4-06/05 & $\begin{array}{l}\text { BAHIA, Paulo Afonso, Xingó Reservoir, downstream } \\
\text { Sal River, upstream from curve of gorge, from right } \\
\text { margin, lentic, } 06.05 .2015^{3}\end{array}$ & 144 & $\begin{array}{l}9^{\circ} 26 ’ 31.99 " S \\
38^{\circ} 07^{\prime} 17.57^{\prime \prime} \mathrm{W}\end{array}$ & $\begin{array}{l}\text { FUEL } \\
58040\end{array}$ \\
\hline AL5-06/05 & $\begin{array}{l}\text { ALAGOAS, Delmiro Gouveia, Xingó Reservoir, } \\
\text { downstream of Sal River, downstream from curve } \\
\text { of gorge, middle, lentic, } 06.05 .2015^{3}\end{array}$ & 140 & $\begin{array}{l}9^{\circ} 26^{\prime} 17.85 " S \\
38^{\circ} 06^{\prime} 54.63 " \mathrm{~W}\end{array}$ & $\begin{array}{l}\text { FUEL } \\
58041\end{array}$ \\
\hline AL6-06/05 & $\begin{array}{l}\text { BAHIA, Paulo Afonso, Xingó Reservoir, downstream } \\
\text { Sal River, downstream from curve of gorge, middle, } \\
\text { lentic, } 06.05 .2015^{3}\end{array}$ & 140 & $\begin{array}{l}9^{\circ} 26 ’ 20.77 " S \\
38^{\circ} 05^{\prime} 17.28 " S\end{array}$ & $\begin{array}{l}\text { FUEL } \\
58042\end{array}$ \\
\hline AL7-06/05 & $\begin{array}{l}\text { ALAGOAS, Delmiro Gouveia, Xingó Reservoir, } \\
\text { reentrance of the temporary Salgado River, } \\
\text { water intake for city of Delmiro Gouveia, lentic, } \\
06.05 .2015^{3}\end{array}$ & 140 & $\begin{array}{l}9^{\circ} 27^{\prime} 32.59 " \mathrm{~S} \\
38^{\circ} 01^{\prime} 59.50 " \mathrm{~W}\end{array}$ & $\begin{array}{l}\text { FUEL } \\
58043\end{array}$ \\
\hline AL8-06/05 & $\begin{array}{l}\text { ALAGOAS, Delmiro Gouveia, Xingó Reservoir, } \\
\text { reentrance of temporary river, point of sewage } \\
\text { oputlet of city of Delmiro Gouveia, lentic, } 06.05 .2015^{3}\end{array}$ & 140 & $\begin{array}{l}9^{\circ} 27^{\prime} 31.30 " \mathrm{~S} \\
38^{\circ} 01^{\prime} 38.43 " \mathrm{~W}\end{array}$ & $\begin{array}{l}\text { FUEL } \\
58044\end{array}$ \\
\hline AL9-06/05 & $\begin{array}{l}\text { ALAGOAS, Delmiro Gouveia, Xingó Reservoir, next } \\
\text { to Bode Island, middle, lentic, } 06.05 .2015^{3}\end{array}$ & 140 & $\begin{array}{l}9^{\circ} 31^{\prime} 46.23 " \mathrm{~S} \\
37^{\circ} 58^{\prime} 30.73 \text { 'W }\end{array}$ & $\begin{array}{l}\text { FUEL } \\
58045\end{array}$ \\
\hline AL10-06/05 & $\begin{array}{l}\text { ALAGOAS, Piranhas, Xingó Reservoir, next to dam, } \\
\text { upstream, lentic, } 06.05 .2015^{3}\end{array}$ & 140 & $\begin{array}{l}\text { 9॰36'27.35"S; } \\
37^{\circ} 48^{\prime} 31.82 " \mathrm{~W}\end{array}$ & $\begin{array}{l}\text { FUEL } \\
58046\end{array}$ \\
\hline AL1-18/05 & $\begin{array}{l}\text { ALAGOAS, Delmiro Gouveia, São Francisco River, } \\
\text { between dam I, II, III and dam IV of Paulo Afonso } \\
\text { Reservoir, downstream, lotic, } 18.05 .2015^{3}\end{array}$ & 167 & $\begin{array}{c}\text { 9²4'36.37"S; } \\
38^{\circ} 12^{\prime} 13.52 " \mathrm{~W}\end{array}$ & $\begin{array}{l}\text { FUEL } \\
58047\end{array}$ \\
\hline AL2-18/05 & $\begin{array}{l}\text { ALAGOAS, Delmiro Gouveia, Xingó Reservoir, } \\
\text { gorge, upstream of Sal River, lentic, 18.05.2015³ }\end{array}$ & 149 & $\begin{array}{l}9^{\circ} 25^{\prime} 58.00 " \mathrm{~S} \\
38^{\circ} 10^{\prime} 09.08^{\prime \prime} \mathrm{W}\end{array}$ & $\begin{array}{l}\text { FUEL } \\
58048\end{array}$ \\
\hline AL3-18/05 & $\begin{array}{l}\text { ALAGOAS, Delmiro Gouveia, Xingó Reservoir, } \\
\text { downstream from Sal River, upstream from curve of } \\
\text { gorge, to the left margin, lentic, } 18.05 .2015^{3}\end{array}$ & 144 & $\begin{array}{c}\text { 9²6'25.10"S; } \\
38^{\circ} 07^{\prime} 18.12 " \mathrm{~W}\end{array}$ & $\begin{array}{l}\text { FUEL } \\
58049\end{array}$ \\
\hline AL4-18/05 & $\begin{array}{l}\text { BAHIA, Paulo Afonso, Xingó Reservoir, downstream } \\
\text { Sal River, upstream from curve of gorge, at right } \\
\text { margin, lentic, } 18.05 .2015^{3}\end{array}$ & 144 & $\begin{array}{c}9^{\circ} 26 \text { '31.99"S; } \\
38^{\circ} 07^{\prime} 17.57^{\prime \prime} \mathrm{W}\end{array}$ & $\begin{array}{l}\text { FUEL } \\
58050\end{array}$ \\
\hline AL5-18/05 & $\begin{array}{l}\text { ALAGOAS, Delmiro Gouveia, Xingó Reservoir, } \\
\text { downstream from Sal River, downstream from curve } \\
\text { of gorge, middle, lentic, } 18.05 .2015^{3}\end{array}$ & 140 & $\begin{array}{c}9^{\circ} 26^{\prime} 17.85^{\prime \prime S} ; \\
38^{\circ} 06^{\prime} 54.63 " \mathrm{~W}\end{array}$ & $\begin{array}{l}\text { FUEL } \\
58051\end{array}$ \\
\hline AL6-18/05 & $\begin{array}{l}\text { BAHIA, Paulo Afonso, Xingó Reservoir, downstream } \\
\text { Sal River, downstream from curve of gorge, middle, } \\
\text { lentic, } 18.05 .2015^{3}\end{array}$ & 140 & $\begin{array}{l}9^{\circ} 26 \text { '20.77"S; } \\
38^{\circ} 05^{\prime} 17.28 " S\end{array}$ & $\begin{array}{l}\text { FUEL } \\
58052\end{array}$ \\
\hline AL7-18/05 & $\begin{array}{l}\text { ALAGOAS, Delmiro Gouveia, Xingó Reservoir, } \\
\text { reentrance of temporary Salgado River, water intake } \\
\text { of city of Delmiro Gouveia, lentic, } 18.05 .2015^{3}\end{array}$ & 140 & $\begin{array}{c}9^{\circ} 27^{\prime} 32.59 " \mathrm{~S} ; \\
38^{\circ} 01^{\prime} 59.50 " \mathrm{~W}\end{array}$ & $\begin{array}{l}\text { FUEL } \\
58053\end{array}$ \\
\hline
\end{tabular}

1 Collectors: I.S. Nogueira, S.M. Pessoa, S.H.M. Benício and L.C.P. Prado; 2 Collector: S.M. Santos; 3 Collector: E.M.M. Magalhães. 
Table 1. Continued...

\begin{tabular}{|c|c|c|c|c|}
\hline Sample Code & Description & $\begin{array}{l}\text { Altitude } \\
\text { (m a.s.I.) }\end{array}$ & Coordinates & $\begin{array}{c}\text { Herbarium } \\
\text { number }\end{array}$ \\
\hline AL8-18/05 & $\begin{array}{l}\text { ALAGOAS, Delmiro Gouveia, Xingó Reservoir, } \\
\text { reentrance of temporary river, point of sewage outlet } \\
\text { of city of Delmiro Gouveia, lentic, } 18.05 .2015^{3}\end{array}$ & 140 & $\begin{array}{l}9^{\circ} 27^{\prime} 31.30 " S \\
38^{\circ} 01^{\prime} 38.43^{\prime \prime} \mathrm{W}\end{array}$ & $\begin{array}{l}\text { FUEL } \\
58054\end{array}$ \\
\hline AL9-18/05 & $\begin{array}{l}\text { ALAGOAS, Delmiro Gouveia, Xingó Reservoir, next } \\
\text { to Bode Island, middle, lentic, } 18.05 .2015^{3}\end{array}$ & 140 & $\begin{array}{l}9^{\circ} 31^{\prime} 46.23 " \mathrm{~S} \\
37^{\circ} 58 \text { ' } 30.73^{\prime \prime} \mathrm{W}\end{array}$ & $\begin{array}{l}\text { FUEL } \\
58055\end{array}$ \\
\hline AL10-18/05 & $\begin{array}{l}\text { ALAGOAS, Piranhas, Xingó Reservoir, next to dam, } \\
\text { upstream, lentic, } 18.05 .2015^{3}\end{array}$ & 140 & $\begin{array}{l}9^{\circ} 36^{\prime} 27.35^{\prime \prime S} \\
37^{\circ} 48^{\prime} 31.82^{\prime \prime} \mathrm{W}\end{array}$ & $\begin{array}{l}\text { FUEL } \\
58056\end{array}$ \\
\hline
\end{tabular}

1 Collectors: I.S. Nogueira, S.M. Pessoa, S.H.M. Benício and L.C.P. Prado; 2 Collector: S.M. Santos; 3 Collector: E.M.M. Magalhães.

fixed with Lugol's solution (Bicudo \& Menezes, 2006).

Morphological analyses were performed with a Zeiss Axioscope 40 optical microscope (LM) equipped with an Axiocam HRc digital camera (Carl Zeiss Microscopy GmbH, Germany). Thecal plates were dyed with $1 \%$ calcofluor white (Fritz \& Triemer, 1985) and observed in an Olympus BX51 epifluorescence microscope (EM, Olympus, Tokyo, Japan) with a QCapture Suite image system, version 2.68 (QImaging, Bethesda, MD, USA). The metric features were obtained using the AxioVision Rel 4.8 image software (Carl Zeiss Microscopy GmbH, Germany).

For scanning electron microscopy (SEM) analyses, small probes of each material were fixed with glutaraldehyde for $1 \mathrm{~h}$ and dehydrated in an acetyl alcohol series series of 20, 40, 60, 80 and 100\%, for $150 \mathrm{~min}$. Part of the dehydrated material was deposited under cover slips and dried in desiccators using silica. The cover slips were fixed on aluminum stubs, using carbon-conductive ink. The material was sputtered with a layer of gold in a Desk V sputter coater (Denton Vacuum, LLC). The preparations were analyzed in a Jeol JSM-6610 scanning electron microscope (Jeol, USA), with an electrical potential of $6 \mathrm{kV}$, spotsize 25-40.

Individuals of $C$. furcoides were quantified with the Utermöhl method (Utermöhl, 1958) using a Zeiss Axiovert 25 microscope (Carl Zeiss Microscopy GmbH, Germany), and were expressed in cell density (cells. $\mathrm{mL}^{-1}$ ). The species was identified according to Hickel (1988), Popovský \& Pfiester (1990), and Matsumura-Tundisi et al. (2010). The phytoplankton biovolume was obtained by multiplying the population density by the volume of individuals, based on the stereometric formula proposed by Cabeçadas (2011).

In the Corumbá and João Leite river basins, physical and chemical variables including water temperature, $\mathrm{pH}$, oxidation-reduction potential
(ORP), electrical conductivity, turbidity, dissolved oxygen (DO), and total dissolved solids (TDS) were obtained using a Horiba U21 multiparameter water quality meter. In the João Leite River basin, concentrations of nitrate and total phosphorus (TP) were measured according to APHA (2005). The data for these variables from the São Francisco River Basin were obtained from Technical Report DILAB 003/2015 (http://cbhsaofrancisco.org. br/?wpfb_dl=1980).

\section{Results}

Ceratium furcoides (Levander) Langhans (1925, p. 597) (Figures 1-7, 8-10).

Basionym: C. hirundinella var. furcoides Levander

Remarks: Individuals of Ceratium showed tabulation formula 4' (one does not reach the apex), 6", 6c, 6"', 2"”. Specimens from the Corumbá River basin, including in Cascatinha Falls, were characterized by length $148-178 \mu \mathrm{m}$, breadth 41-55, and thickness $27-29 \mu \mathrm{m}$; in the São Francisco River Basin, the individuals showed length 106-141 $\mu \mathrm{m}$, breadth 31-42 $\mu \mathrm{m}$, and thickness 10-14 $\mu \mathrm{m}$.

C. furcoides reached 2,050 cells. $\mathrm{mL}^{-1}$ and a biovolume of $112.51 \mathrm{~mm}^{3} \cdot \mathrm{L}^{-1}$ in Corumbá Reservoir (Table 2). In Joáo Leite Reservoir, the density varied from 39 to 137 cells. $\mathrm{mL}^{-1}$, and the biovolume from 2.14 to $7.51 \mathrm{~mm}^{3}$. $\mathrm{L}^{-1}$. In the São Francisco River, the density varied from 2.0 to 5,600 cells. $\mathrm{mL}^{-1}$ and the biovolume from 0.04 to $112.80 \mathrm{~mm}^{3} \cdot \mathrm{L}^{-1}$.

The physical and chemical characteristics of the environments in which $C$. furcoides was recorded were variable (Table 3 ).

\section{Discussion}

Two species of Ceratium have been recorded in Brazilian aquatic systems: C. furcoides and C. hirundinella (Cavalcante et al., 2013). The main 


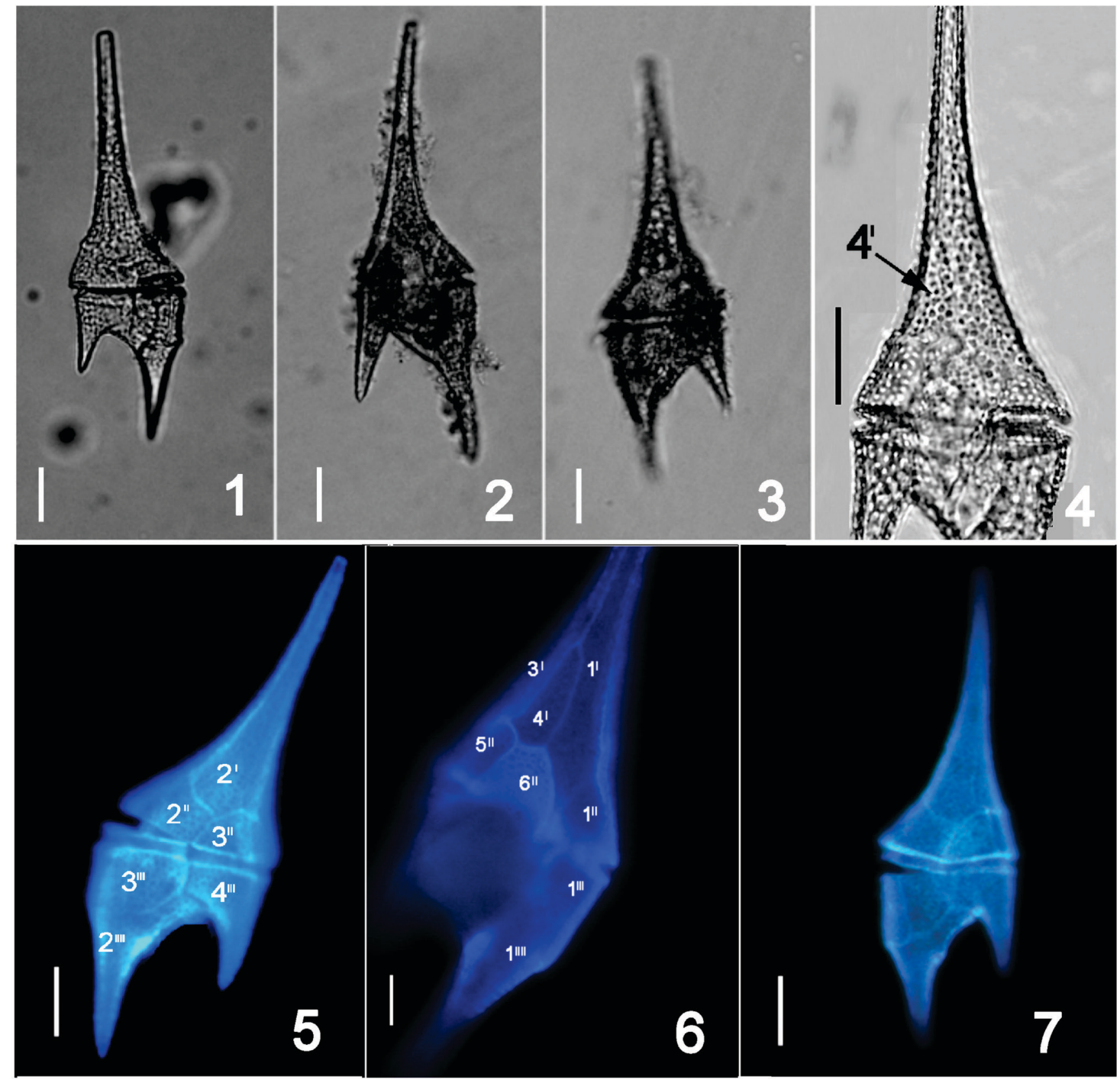

Figures 1-7. Ceratium furcoides. Figures 1-4: light microscopy. Figures 5-7: epifluorescence microscope. Figures 1-4, 7: Population from Corumbá Reservoir, Goiás. Figure 4: Detail of fourth apical plate that does not reach the apex. Figures 5-6: Populations from São Francisco River. Figure 5: Cell in dorsal view showing the apical (2'), precingular (2" and 3"), postcingular (3"' and 4"') and antapical (2"”) plates. Figure 6. Cell in ventral view showing the apical (1', 3' and 4'), precingular (1", 5" and 6”), postcingular (1"') and antapical (1"') plates; note the fourth apical plate (4') not reaching the apex. Scale bars: $20 \mu \mathrm{m}$.

differences in these species are the shape and size of the plate 4", which does not reach the apex in C. furcoides (Matsumura-Tundisi et al., 2010). This characteristic was observed in specimens found in the São Francisco River, João Leite and Corumbá Reservoirs, confirming the identity of this taxon as C. furcoides (Figures 4, 6, 9, 10).

The dimensions of $C$. furcoides were not provided in the original description (Levander, 1894). However, subsequent descriptions reported lengths from 114 to $322 \mu \mathrm{m}$ and widths from 28 to $54 \mu \mathrm{m}$ (Daily, 1960; Hickel, 1988; Moreira et al., 2015; Nishimura et al., 2015; Campanelli et al., 2017). The only values for thickness were provided by
Hickel (1988), from 20 to $25 \mu \mathrm{m}$. The dimensions of the material from João Leite, Corumbá and São Francisco River basins agree with these data, and smaller specimens were observed in populations from the São Francisco River basin (106-141 vs. $114-322 \mu \mathrm{m})$.

There is no consensus about the environmental conditions that contribute to the establishment of C. furcoides. Species of Ceratium have been observed in deep and shallow environments, oligo- to eutrophic, and medium to large sizes (Padisák et al., 2009). More specifically, C. furcoides has been positively related to ammonium concentrations and negatively related to alkalinity, nitrate concentration, 
Table 2. Density and biovolume of Ceratium furcoides in Corumbá Reservoir and São Francisco River (for sites codes, see Table 1).

\begin{tabular}{cccc}
\hline Sites & Type of environment & Density $\left(\mathbf{c e l l s} \cdot \mathbf{m L}^{-1}\right)$ & Biovolume $\left(\boldsymbol{\mu} \mathbf{m}^{3} \cdot \mathbf{L}^{-1}\right)$ \\
\hline GO-Cor-MID & Lentic & 2,050 & 112.51 \\
GO-JL-15/03 & Lentic & 39 & 2.14 \\
GO-JL-24/05 & Lentic & 137 & 7.51 \\
AL1-06/05 & Lotic & 20 & 0.40 \\
AL1-18/05 & Lotic & 2 & 0.04 \\
AL2-06/05 & Lentic & 100 & 2.01 \\
AL2-18/05 & Lentic & 3 & 0.06 \\
AL3-06/05 & Lentic & 780 & 15.71 \\
AL3-18/05 & Lentic & 3 & 0.06 \\
AL4-06/05 & Lentic & 120 & 2.42 \\
AL4-18/05 & Lentic & 5,600 & 112.80 \\
AL5-06/05 & Lentic & 3,800 & 76.54 \\
AL5-18/05 & Lentic & 3,720 & 74.93 \\
AL6-06/05 & Lentic & 4,660 & 93.87 \\
AL6-18/05 & Lentic & 2,070 & 41.70 \\
AL7-06/05 & Lentic & 5,280 & 106.36 \\
AL7-18/05 & Lentic & 760 & 15.31 \\
AL8-06/05 & Lentic & 1,880 & 37.87 \\
AL8-18/05 & Lentic & 3,400 & 68.49 \\
AL9-06/05 & Lentic & 140 & 2.82 \\
AL9-18/05 & Lentic & 510 & 10.27 \\
AL10-06/05 & Lentic & 180 & 3.63 \\
AL10-18/05 & Lentic & 100 & 2.01 \\
\hline
\end{tabular}

Table 3. Mean values of physical and chemical variables analyzed in reservoirs and rivers in the Corumbá River basin, Goiás, and the São Francisco River basin, Alagoas (ORP: oxidation-reduction potential; DO: dissolved oxygen; TDS: total dissolved solids).

\begin{tabular}{lcccc}
\hline \multirow{2}{*}{ Variables } & \multicolumn{4}{c}{ Sites } \\
\cline { 2 - 5 } & $\begin{array}{c}\text { Cascatinha Falls } \\
(n=\mathbf{2})\end{array}$ & $\begin{array}{c}\text { Corumbá Reservoir } \\
(n=\mathbf{4})\end{array}$ & $\begin{array}{c}\text { João Leite } \\
\text { Reservoir } \\
(n=7)\end{array}$ & $\begin{array}{c}\text { São Francisco } \\
\text { River } \\
(n=\mathbf{4})\end{array}$ \\
\hline Water temperature $\left({ }^{\circ} \mathrm{C}\right)$ & 22.89 & 26.57 & 26.64 & 29.89 \\
pH & 8.14 & 6.79 & 7.34 & 6.42 \\
Conductivity $\left(\mu \mathrm{S} . \mathrm{cm}^{-1}\right)$ & 10.00 & 39.00 & 113.00 & 75.00 \\
Turbidity $(\mathrm{NTU})$ & 0.86 & 38.98 & 9.70 & 15.3 \\
DO $\left(\mathrm{mg} . \mathrm{L}^{-1}\right)$ & 26.63 & 18.23 & 6.46 & 11.69 \\
TDS $\left(\mathrm{mg} \cdot \mathrm{L}^{-1}\right)$ & 6.00 & 25.00 & - & 49.00 \\
Nitrate $\left(\mathrm{mg} \cdot \mathrm{L}^{-1}\right)$ & - & - & 0.25 & 0.81 \\
Total phosphorus $\left(\mathrm{mg} . \mathrm{L}^{-1}\right)$ & - & - & 0.02 & 0.86 \\
\hline
\end{tabular}

DO, silicates, and light availability in environments in Colombia (Gil et al., 2012). In Brazilian environments, this species has shown better development in environments with higher nitrite and nitrate concentrations with deep euphotic zones, as in Billings Reservoir (Nishimura et al., 2015), or in mesotrophic environments, with warmer temperatures and higher electrical conductivity (Silva et al., 2012). Cavalcante et al. (2016) found that high organic-matter content, nutrient availability, well-oxygenated water and temperatures from 15 to $25^{\circ} \mathrm{C}$ are the main environmental factors that contribute to the establishment of C. furcoides in reservoirs in southern Brazil. In this study, the João Leite, Corumbá and São Francisco systems were acid to slightly alkaline, and the water temperatures were above $25^{\circ} \mathrm{C}$. Moreover, it is not clear if well-oxygenated water is a favorable condition for the development of this species or is a result of its development, since oxygen is a product of photosynthesis Thus, this species has occurred in environments with different DO concentrations; 


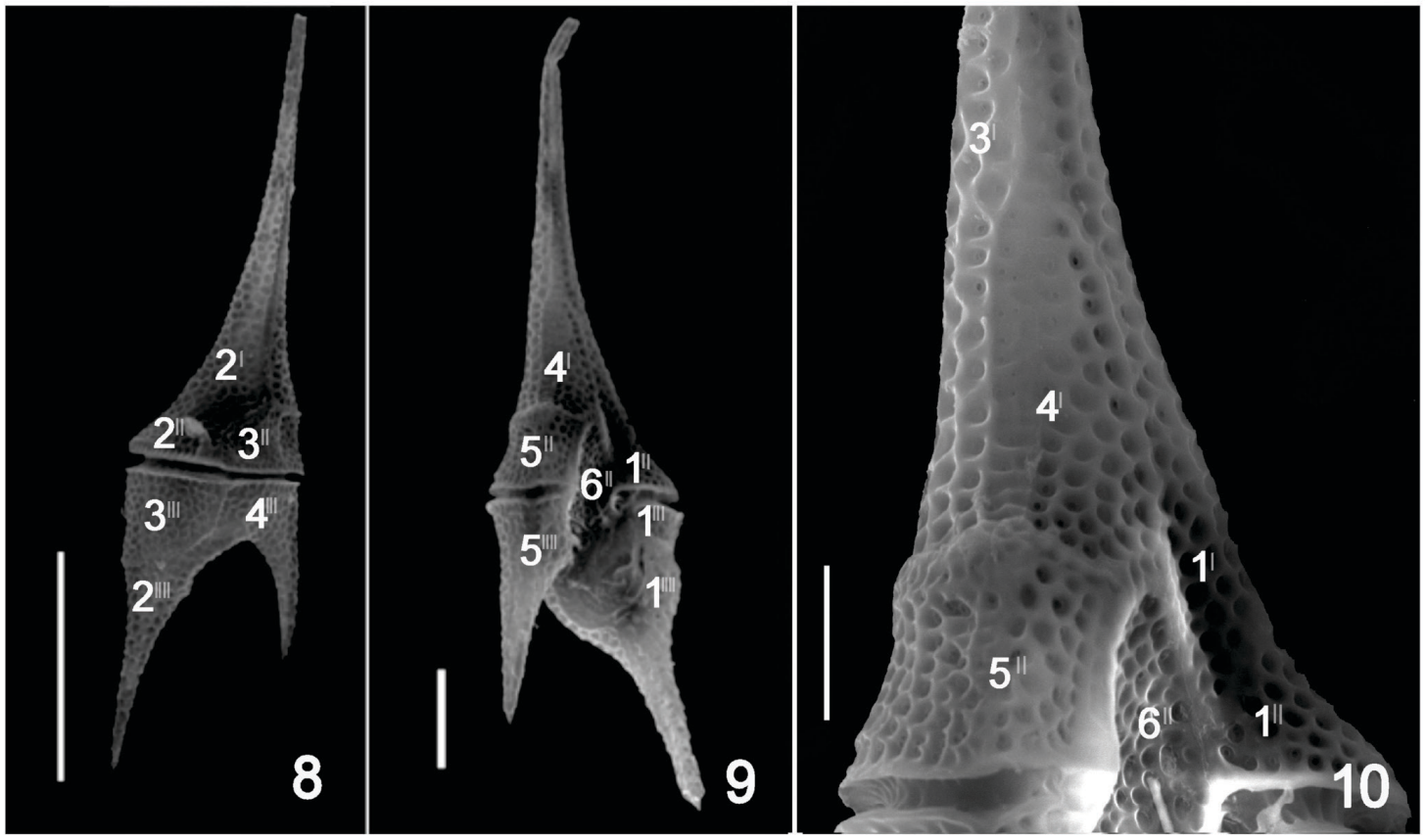

Figures 8-10. C. furcoides, population from Corumbá Reservoir, Goiás, in SEM. Figure 8: Cell in dorsal view showing the apical (2'), precingular (1" and 5"), postcingular (4"' and 3"') and antapical (2"') plates. Figure 9: Cell in ventral view showing the apical (4'), precingular (1", 5” and 6”), postcingular (1"' and 5”') and antapical (1"”) plates; note the fourth apical plate (4') not reaching the apex. Figure 10: Detail of epitheca in dorsal view. Scale bars: Figure $8=50 \mu \mathrm{m}$; Figure $9=20 \mu \mathrm{m}$; Figure $10=10 \mu \mathrm{m}$.

e.g., in João Leite DO concentrations were low, in contrast to the Corumbá and São Francisco systems. Organic matter can also be influenced by the high biovolumes of this species. Despite the values of nutrient concentrations are sparse in the environments studied here, these resources seem facilitate the establishment and development of the species. Crossetti et al. (2018) observed that the recurrence of $C$. furcoides in Garças reservoir was associated with higher transparency, lower water stability, higher dissolved inorganic nitrogen and lower TP values.

C. furcoides is hitherto known in Brazil in aquatic environments from the Paraná River, São Francisco River, Atlantic (East/South regions), and Uruguay River basins. No records have been reported from the Amazon River, Tocantins-Araguaia River or Atlantic (North/Northeast) basins, nor in some other parts of the world (Figures 11 and 12). The establishment of $C$. furcoides in Brazilian aquatic systems is a recent event (Santos-Wisniewski et al., 2007; Cavalcante et al., 2013). Based on the dates of occurrence, Cavalcante et al. (2013) hypothesized that the dispersal of $C$. furcoides seems to be radial, i.e., northward and southward from the initial appearance in the southeastern region. However, the relationships among the populations in the different Brazilian aquatic systems have not been studied.

In several cases, $C$. furcoides was observed in very low densities and did not appear in quantitative samples, such as at Cascatinha Falls. This suggests that the species may be present in some environments but not in sufficient numbers to be recorded. The failure to find it in some samples may also indicate methodological problems during sampling, since species of Ceratium can migrate vertically. Almost all samples taken in Brazilian waterbodies are from the subsurface. However, in some cases, high densities of species of Ceratium can be found down to $7 \mathrm{~m}$, where light conditions are more suitable or due to stratification (Harris et al., 1979). In some aquatic systems in Brazil where C. furcoides was found, no temporal records exist, which makes the time of its arrival uncertain. These problems add to the uncertainty regarding the actual localities where this species occurs and its distribution patterns.

For some environments in Brazil, it is possible to infer an approximate date of the invasion because of long-term historical floristic studies, such as in Billings Reservoir (Matsumura-Tundisi et al., 2010; Nishimura et al., 2015). Because the João 


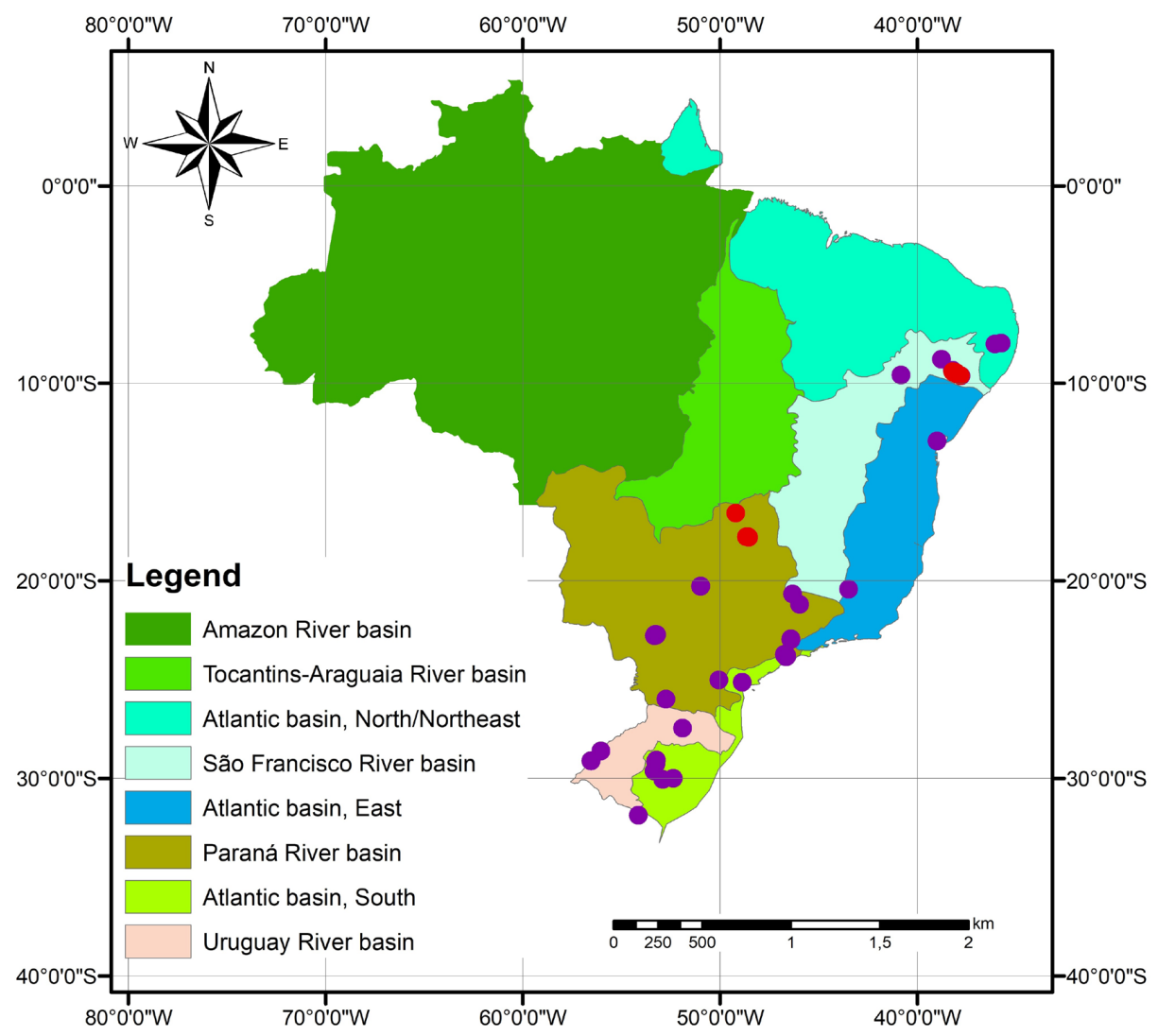

Figure 11. Occurrence of Ceratium furcoides in Brazilian aquatic systems, showing previous records (purple dots) and new records from central-western Brazil and the northeast (red dots).

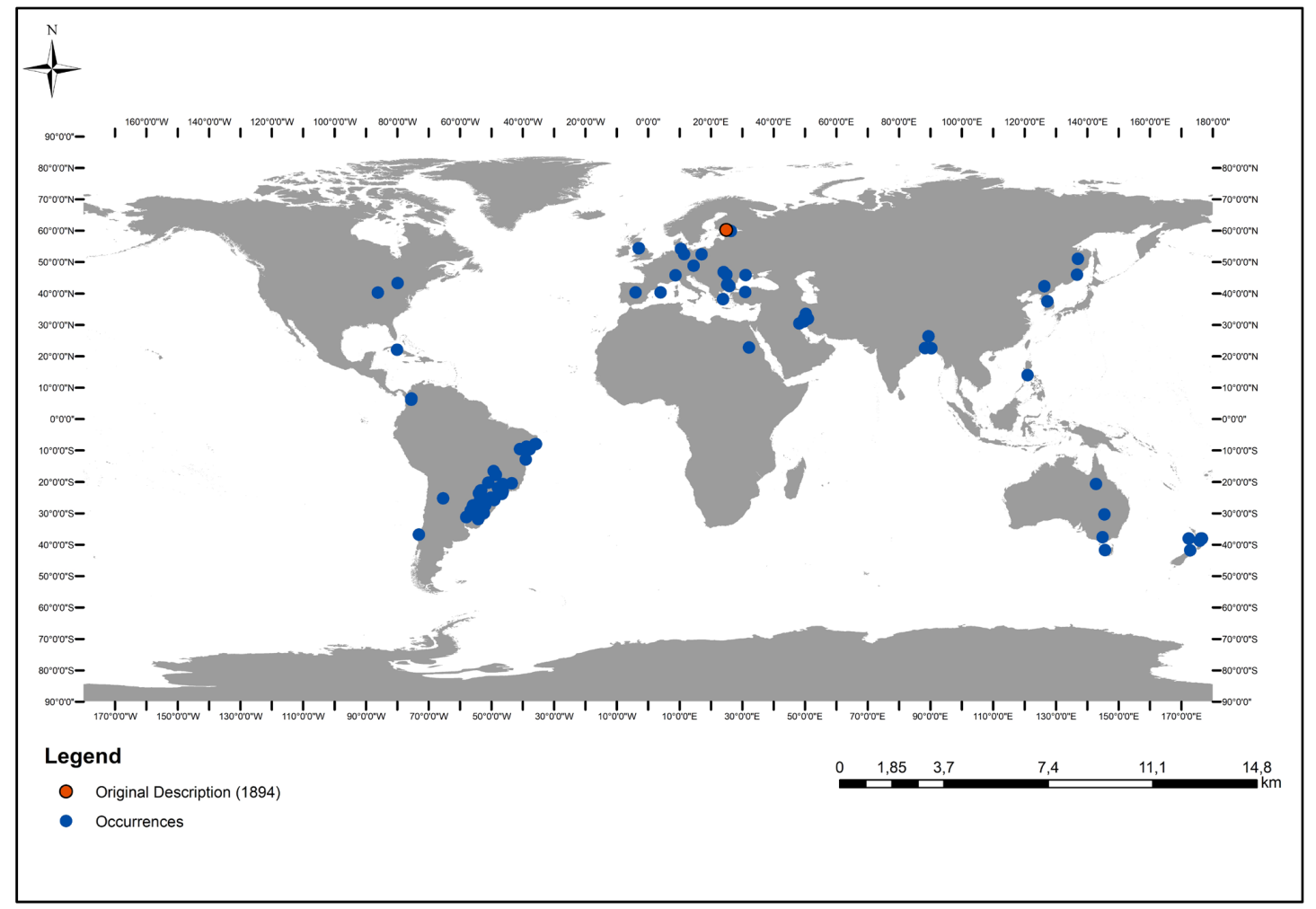

Figure 12. Occurrence of Ceratium furcoides in the world. 
Leite River basin is the water source for the metropolitan region of Goiânia, the biotic and abiotic conditions of this system have been long exhaustively monitored, mainly after the creation of the reservoir in 2009 (Cunha \& Borges, 2015). Thus, $C$. furcoides certainly did not occur in this environment before March 2016. Historical studies of the phytoplankton composition in Corumbá Reservoir are scarce, but the existing studies support the hypothesis that $C$. furcoides did not occur there before 2011 (Silva et al., 2001; I. S. Nogueira, pers. observ.).

While the answer for "when" C. furcoides arrives in Brazilian waterbodies seems to be easier to propose, "how" it occur and is occurring is still not possible to verify. Some researchers suggest by boats or migratory birds as some of the main dispersive ways for phytoplanktonic species (Padisák et al., 2016). From that, the establishment of this species in Brazilian waters and its spread can be associated to adequate environmental conditions and drivers upstream-downstream or downstream-upstream. Until 2011, C. furcoides was observed in only two hydrographic regions, Paraná and Sáo Francisco. The existence of cascades of reservoirs in large rivers is presumed to contribute considerably to its spread (Padisák et al., 2016). This seems to be a reaseonable explanation for invasions at the upstream-downstream direction. Corumbá and João Leite reservoirs are in the Paraná Hydrographic Region, upstream of the systems where $C$. furcoides was previously recorded.

This sugest the progression of the invasion of this species in aquatic systems toward the central-northern region.

The continuous progression of this species, reaching aquatic systems in the state of Goiás, should be considered and studied. This state contains a watershed divide between tributaries of three of the main river basins of the country. Although these river basins are mostly separated by high-altitude formations, these seem not to limit the movement of $C$. furcoides, since the species occurs in high-altitude systems (Moreira et al., 2015). This suggests that the distribution pattern is more complex than can be explained by the connectivity of aquatic systems. However, this factor may facilate its spread, as in the case of reservoir cascades in large rivers, which are presumed to contribute considerably to the establishment of $C$. furcoides (Padisák et al., 2016).

The harmful of $C$. furcoides is few known. Despite this species is not toxic, it reach great density during some phases because the low preference by grazers and (Santer, 1996) and good enviromental conditions (Crossetti et al., 2018). Similar blooms have contributed to high depletion of oxygen in water column and consequently fish-kill in some lakes and problems in water treatment (Nicholls et al., 1980). Understanding the occurrences and distribution patterns of $C$. furcoides is essential to the development of control policies, which should be used to guarantee the future water quality of Brazilian aquatic systems for different uses in a period when drinking water is becoming scarce. Promptly detecting the occurrence of an invasive species such as $C$. furcoides is essential to understand the ecological factors that can facilitate the establishment of this species and to develop models to prevent its spread (Lennox et al., 2015; Mazzamuto et al., 2016). Future studies should analyze the relationships among populations of C. furcoides in Brazil, and make efforts to discover the mechanisms related to the expansion success of this species.

\section{Acknowledgements}

WJS and SHMB thank CAPES (Coordination for the Improvement of Higher Education Personnel) for scholarships, respectively, of a Post Doctorate (PNPD/CAPES) in 2013-2015 and a Master's degree in 2014-2016.

\section{References}

ALMANZA, V., BICUDO, C.E.M., PARRA, O. and URRUTIA, R. Características morfológicas y limnológicas de las floraciones de Ceratium furcoides (Dinophyta) en un lago somero de Chile Central. Limnetica, 2016, 35(1), 253-268.

ALMEIDA, C.R., SPIANDORELLO, F.B., GIROLDO, D. and YUNES, J.S. The effectiveness of conventional water treatment in removing Ceratium furcoides (Levander) Langhans, Microcystis sp. and microcystins. Water S.A., 2016, 42(4), 606611. http://dx.doi.org/10.4314/wsa.v42i4.11.

ALPERT, P., BONE, E. and HOLZAPFEL, C. Invasiveness, invasibility and the role of environmental stress in the spread of non-native plants. Perspectives in Plant Ecology, Evolution and Systematics, 2000, 3(1), 52-66. http://dx.doi.org/10.1078/1433-831900004.

AMERICAN PUBLIC HEALTH ASSOCIATION APHA. Standard methods for examination of water and wastewater. Washington: American Public Health Association, 2005.

BERTHON, K. How do native species respond to invaders? Mechanistic and trait-based perspectives. 
Biological Invasions, 2015, 17(8), 2199-2211. http:// dx.doi.org/10.1007/s10530-015-0874-7.

BICUDO, C.E.D.M. and MENEZES, M. Gêneros de águas continentais do Brasil. São Carlos: Rima, 2006.

BORDET, F., FONTANARROSA, M.S. and O'FARRELL, I. Influence of light and mixing regime on bloom-forming phytoplankton in a subtropical reservoir. River Research and Applications, 2017, 33(8), 1315-1326. http://dx.doi.org/10.1002/ rra.3189.

BRASIL. Ministério do Meio Ambiente, Secretaria de Recursos Hídricos. Caderno da Regiāo Hidrográfica do São Francisco. Brasília: MMA, 2006.

BRESSANE, L.W., MARTINS, R. and MENDES, R.B. Análise da comunidade fitoplanctônica na represa de Furnas em Barranco Alto - MG. Forum Ambiental da Alta Paulista, 2013, 9(2), 51-68.

CABEÇADAS, L. Discussão de resultados, identificação e determinação de biovolume - formas complexas. Ensaio Laboratorial de Fitoplâncton-2011. Lisboa: Agencia Portuguesa do Ambiente, 2011.

CALADO, A.J. and LARSEN, J. On the identity of the type species of the genus Ceratium Schrank (Dinophyceae), with notes on $C$. hirundinella. Phycologia, 1997, 36(6), 500-505. http://dx.doi. org/10.2216/i0031-8884-36-6-500.1.

CAMPANELLI, L.C., TUNDISI, J.G., ABE, D.S., SIDAGIS-GALLI, C. and MATSUMURATUNDISI, T. Record of the occurrence of dinoflagellate Ceratium furcoides in a fish farming lake located in the countryside of São Carlos (SP, Brazil). Brazilian Journal of Biology $=$ Revista Brasileira de Biologia, 2017, 77(2), 426-427. http://dx.doi. org/10.1590/1519-6984.06916. PMid:27579971.

CAPUTO GALARCE, L., RIQUELME, K., OSMAN, D. and FUENTES, R. A new record of the non indigenous freshwater jellyfish Craspedacusta sowerbii Lankester, 1880 (Cnidaria) in Northern Patagonia (40 S, Chile). BioInvasions Records, 2013, 2(4), 263-270. http://dx.doi.org/10.3391/bir.2013.2.4.01.

CASSIE, V. Seasonal changes in phytoplankton densities in four North Island lakes, 1973-74. New Zealand Journal of Marine and Freshwater Research, 1978, 12(2), 153-166. http://dx.doi.org/10.1080/00288 330.1978 .9515736 .

CASSOL, A.P.V., OLIVEIRA, M.A., DOMINGUES, A.L., PEREIRA-FILHO, W., DURIGON, M. and SILVA, J.F. Climate factors and limnological conditions shaping phytoplankton community in two subtropical cascading reservoirs. Acta Limnologica Brasiliensia, 2017, 29(0), e17. http://dx.doi. org/10.1590/s2179-975x6316.

CASSOL, A.P.V., PEREIRA FILHO, W., OLIVEIRA, M.A., DOMINGUES, A.L., CORREA, F.S. and BURIOL, G.A. First record of a bloom of the invasive species Ceratium furcoides (Levander) Langhans 1925 in Rio Grande do Sul state, Brazil. Brazilian Journal of Biology = Revista Brasileira de Biologia, 2014, 74(2), 515-517. http://dx.doi.org/10.1590/15196984.05413. PMid:25166340.

CAVALCANTE, K.P., CARDOSO, L.S., SUSSELLA, R. and BECKER, V. Towards a comprehension of Ceratium (Dinophyceae) invasion in Brazilian freshwaters: autecology of $C$. furcoides in subtropical reservoirs. Hydrobiologia, 2016, 771(1), 265-280. http://dx.doi.org/10.1007/s10750-015-2638-x.

CAVALCANTE, K.P., CRAVEIRO, S.C., CALADO, A.J., LUDWIG, T.A.V. and CARDOSO, L.S. Diversity of freshwater dinoflagellates in the state of Paraná, Southern Brazil, with taxonomic and distributional notes. Fottea, 2017, 17(2), 240-263. http://dx.doi.org/10.5507/fot.2016.026.

CAVALCANTE, K.P., ZANOTELLI, J.C., MÜLLER, C.C., SCHERER, K.D., FRIZZO, J.K., LUDWIG, T.A.V. and CARDOSO, L.S. First record of expansive Ceratium Schrank, 1793 species (Dinophyceae) in Southern Brazil, with notes on their dispersive patterns in Brazilian environments. Check List, 2013, 9(4), 862-866. http://dx.doi.org/10.15560/9.4.862.

ÇELEKLI, A., ALBAY, M. and DUGEL, M. Phytoplankton (except Bacillariophyceae) Flora of Lake Gölköy (Bolu). Turkish Journal of Botany, 2007, 31(1), 49-65.

CHU, G., SUN, Q., RIOUAL, P., BOLTOVSKOY, A., LIU, Q., SUN, P., HAN, J. and LIU, J. Dinocyst microlaminations and freshwater "red tides" recorded in Lake Xiaolongwan, northeastern China. Journal of Paleolimnology, 2008, 39(3), 319-333. http://dx.doi. org/10.1007/s10933-007-9106-1.

COMAS, A. Catálogo de las algas y cianoprocariotas dulciacuicolas de Cuba. Cinfuegos: Editorial Universo Sur, 2009, 147 p.

CROSSETTI, L.O., BICUDO, D.C., BINI, L.M., DALA-CORTE, R.B., FERRAGUT, C. and BICUDO, C.E.M. Phytoplankton species interactions and invasion by Ceratium furcoides are influenced by extreme drought and water-hyacinth removal in a shallow tropical reservoir. Hydrobiologia, 2018, 1-15.

CUNHA, D.F. and BORGES, E.D.M. Urbanização Acelerada: Risco para o Abastecimento de água na Região Metropolitana de Goiânia. Geo UERJ, 2015, 26, 226-244.

DAGA, I.C. and PIEROTTO, M.J. Variaciones espaciales y temporales de organismos autótrofos en el embalse La Quebrada (Córdoba, Argentina). Arnaldoa, 2014, 21(1), 179-186.

DAILY, W.A. Forms of Ceratium hirundinella (O. F. Muller) Schrank in Lakes and Ponds of Indiana. Proceedings of the Indiana Academy of Sciences, 1960, 70, 213-215.

DARKI, B.Z. Recognition of continental dinoflagellates of Iran. Iranian Journal of Botany, 2014, 20(1), 130-142. 
DERMOTT, R., JOHANNSSON, O., MUNAWAR, M., BONNELL, R., BOWEN, K., BURLEY, M., FITZPATRICK, M., GERLOFSMA, J. and NIBLOCK, H. Assessment of lower food web in Hamilton Harbour, Lake Ontario, 2002-2004. Canadian Technical Report of Fisheries and Aquatic Sciences, 2007, 279(1740), 2990-2997.

DOKULIL, M.T. and TEUBNER, K. Steady state phytoplankton assemblages during thermal stratification in deep alpine lakes. Do they occur? Hydrobiologia, 2003, 502(1-3), 65-72. http://dx.doi. org/10.1023/B:HYDR.0000004270.70364.f3.

EL-OTIFY, A.M., SHAFIK, H.M. and SZÖKE, E. Analyses of physico-chemical characteristics and phytoplankton communities of Lake Nasser during the last two decades. Acta Botanica Hungarica, 2003, 45(1), 75-100. http://dx.doi.org/10.1556/ ABot.45.2003.1-2.8.

EPANCHIN-NIELL, R.S. and WILEN, J.E. Optimal spatial control of biological invasions. Journal of Environmental Economics and Management, 2012, 63(2), 260-270. http://dx.doi.org/10.1016/j. jeem.2011.10.003.

FERREIRA, J.A. and AZEVEDO, F.D.A. Fitoplâncton do lago Água Azul, Guarulhos, Brasil: um lago urbano. Review of Education, 2017, 12(2), 25.

FRITZ, L. and TRIEMER, R.E. A rapid simple technique utilizing calcofluor white M2R for the visualization of dinoflagellate thecal plates. Journal of Phycology, 1985, 21(4), 662-664. http://dx.doi. org/10.1111/j.0022-3646.1985.00662.x.

FURNAS. Usina hidrelétrica de Corumbá [online]. Rio de Janeiro: FURNAS, 2015 [Accessed: 25 June 2015]. Available from: http:/www.furnas.com.br/hotsites/ sistemafurnas/usina_hidr_corumba.asp

GIL, C.B., RESTREPO, J.J.R., BOLTOVSKOY, A. and VALLEJO, A. Spatial and temporal change characterization of Ceratium furcoides (Dinophyta) in the equatorial reservoir Riogrande II, Colombia. Acta Limnologica Brasiliensia, 2012, 24(2), 207-219. http:// dx.doi.org/10.1590/S2179-975X2012005000039.

GÓMEZ, F., MOREIRA, D. and LÓPEZ-GARCÍA, P. Neoceratium gen. nov., a new genus for all marine species currently assigned to Ceratium (Dinophyceae). Protist, 2010, 161(1), 35-54. http://dx.doi.org/10.1016/j.protis.2009.06.004. PMid:19665427.

GRIGORSZKY, I., BORICS, G., PADISÁK, J., TÓTMÉRÉSZ, B., VASAS, G., NAGY, S. and BORBÉLY, G. Factors controlling the occurrence of Dinophyta species in Hungary. Hydrobiologia, 2003, 506-509(1-3), 203-207. http://dx.doi.org/10.1023/ B:HYDR.0000008552.60232.68

GUIRY, M.D. and GUIRY, G.M. AlgaeBase. Galway: National University of Ireland, 2016 [viewed 24 July 2016]. Available from: http://www.algaebase.org
GUSMÃO, C.A. and VALSECCHI, J.C. Projeto básico ambiental da barragem e do reservatório de regularização e acumulação do ribeirão João Leite em Goiânia, Goiás - Brasil. Biblioteca virtual desarrollo sostenible y salud ambiental, 2009, 1-16 [viewed 2 Mar 2 2017]. Available from: http://www.bvsde.paho.org/ bvsaidis/puertorico29/gusma.pdf

HACKBART, V.C., MARQUES, A.R.P., KIDA, B.M.S., TOLUSSI, C.E., NEGRI, D.D.B., MARTINS, I.A., FONTANA, I., COLLUCCI, M.P., BRANDIMARTI, A.L., MOSCHINICARLOS, V., SILVA, S.C., MEIRINHO, P.A., FREIRE, R.H.F. and PÔMPEO, M. Avaliação expedita da heterogeneidade espacial horizontal intra e inter reservatórios do sistema Cantareira (Represas Jaguari e Jacareí, São Paulo). In: PÔMPEO, M., MOSCHINI-CARLOS, V., NISHIMURA, P.Y., SILVA, S.C. and DOVAL, J.C.L., eds. Ecologia de reservatórios e interfaces. São Paulo: Instituto de Biociências da Universidade de São Paulo, 2015, pp. 96-108.

HARRIS, G.P., HEANEY, S.I. and TALLING, J.F. Physiological and environmental constraints in the ecology of the planktonic dinoflagellate Ceratium hirundinella. Freshwater Biology, 1979, 9(5), 413428. http://dx.doi.org/10.1111/j.1365-2427.1979. tb01526.x.

HICKEL, B. Sexual reproduction and life cycle of Ceratium furcoides (Dinophyceae) in situ in the lake Plußsee (F.R.). In: JONES, I.R. and ILMAVIRTA, V., eds. Flagellates in Freshwater Ecosystems. Dordecht: Kluwer Academic Publishers, 1988, pp. 41-48. Hydrobiologia 161.

JATI, S., BORTOLINI, J.C., MORESCO, G.A., PAULA, A.C.M., RODRIGUES, L.C., IATSKIU, P., PINEDA, A., ZANCO, B.F., SILVA, M.V. and SOUZA, Y.R. Phytoplankton community in the last undammed stretch of the Paraná River: considerations on the distance from the dam. Acta Limnologica Brasiliensia, 2017, 29(0), e112. http:// dx.doi.org/10.1590/s2179-975x4017.

JATI, S., RODRIGUES, L.C., BORTOLINI, J.C., PAULA, A.C.M., MORESCO, G.A., REIS, L.M., ZANCO, B.F. and TRAIN, S. First record of the occurrence of Ceratium furcoides (Levander) Langhans (Dinophyceae) in the Upper Paraná River Floodplain (PR/MS), Brazil. Brazilian Journal of Biology $=$ Revista Brasileira de Biologia, 2014, 74(3), 235-236. http:// dx.doi.org/10.1590/1519-6984.19313.

JOLLY, V.H. and CHAPMAN, M.A. The comparative limnology of some New Zealand lakes. New Zealand Journal of Marine and Freshwater Research, 1977, 11(2), 307-340. http://dx.doi.org/10.1080/00288 330.1977 .9515680$.

KERNAN, M. Climate change and the impact of invasive species on aquatic ecosystems. Aquatic Ecosystem Health \& Management, 2015, 18(3), 321-333. http:// dx.doi.org/10.1080/14634988.2015.1027636. 
KESHRI, J.P., GHOSH, S., DAS, M., RISHI, S. and KUNDU, N. Freshwater dinoflagellates from Eastern India. NeBio, 2013, 4(6), 9-12.

KHONDKER, M., AZIZ, A., ALFASANE, A. and BHUIYAN, R.A. New records of freshwater dinoflagellates from bangladesh. I. Ceratium, Gymnodinium and Peridinium. Bangladesh Journal of Botany, 2009, 38(1), 65-69.

LANGHANS, V.H. Gemischte Populationen von Ceratium hirundella (O.F.M) schrank und ihre Deutung. Archiv fur Protistenkunde, 1925, 52, 585602.

LENNOX, R., CHOI, K., HARRISON, P.M., PATERSON, J.E., PEAT, T.B., WARD, T.D. and COOKE, S.J. Improving science-based invasive species management with physiological knowledge, concepts, and tools. Biological Invasions, 2015, 17(8), 2213-2227. http://dx.doi.org/10.1007/s10530-0150884-5.

LEVANDER, K.M. Materialien zur Kenntnis der Wasserfauna in der Umgebung Helsingfors, mit besonderer Berücksichtigung der Meeresfauna. I: Protozoa. Acta Societatis pro Fauna et Flora Fennica, 1894, 12(2), 1-155.

LI, Z., SHIN, H.H., LEE, T. and HAN, M.-S. Resting stages of freshwater algae from surface sediments in Paldang Dam Lake, Korea. Nova Hedwigia, 2015, 101(3-4), 475-500. http://dx.doi.org/10.1127/ nova_hedwigia/2015/0284.

LING, H.U. and TYLER, P.A. Australian Freshwater Algae (exclusive of diatoms). Urban Water Research Assoc. of Australia, Project No. 93/109. Bibliotheca Phycologica, 2000, 105, 1-643.

MAC DONAGH, M.E., CASCO, M.A. and CLAPS, M.C. Colonization of a Neotropical Reservoir (Córdoba, Argentina) by Ceratium hirundinella (O. F. Müller) Bergh. Annales de Limnologie - International. Journal of Limnology, 2005, 41(4), 291-299. http:// dx.doi.org/10.1051/limn/2005020.

MATSUMURA-TUNDISI, T., TUNDISI, J.G., LUZIA, A.P. and DEGANI, R.M. Occurrence of Ceratium furcoides (Levander) Langhans 1925 bloom at the Billings Reservoir, São Paulo State, Brazil. Brazilian Journal of Biology $=$ Revista Brasileira de Biologia, 2010, 70(3), 825-829, Supplement. http:// dx.doi.org/10.1590/S1519-69842010000400013. PMid:21085787.

MAZZAMUTO, M.V., GALIMBERTI, A., CREMONESI, G., PISANU, B., CHAPUIS, J.L., STUYCK, J., AMORI, G., SU, H., ALOISE, G., PREATONI, D.G., WAUTERS, L.A., CASIRAGHI, M. and MARTINOLI, A. Preventing species invasion: A role for integrative taxonomy? Integrative Zoology, 2016, 11(3), 214228. http://dx.doi.org/10.1111/1749-4877.12185. PMid:26748591.
MEICHTRY DE ZABURLIN, N., BOLTOVSKOY, A., ROJAS, C.C. and RODRIGUEZ, R.M. Primer registro del dinoflagelado invasor Ceratium furcoides (Levander) Langhans 1925 en la Argentina y su distribución en el área de influencia del Embalse Yacyretá (río Paraná, Argentina-Paraguay). Limnetica, 2014, 33(1), 153-160.

MEICHTRY DE ZABURLÍN, N., GARRIDO, G.G., PESO, J.G. and LLANO, V.M. Programa calidad de agua del Embalse Yacyretá. Informe anual de evaluación 2012-2013. Convenio Entidad Binacional Yacyretá Facultad de Ciencias Exactas, Quimicas y Naturales. Posadas: Universidad Nacional de Misiones, 2013.

MEICHTRY DE ZABURLÍN, N., VOGLER, R.E., MOLINA, M.J. and LLANO, V.M. Potential distribution of the invasive freshwater dinoflagellate Ceratium furcoides (Levander) Langhans (Dinophyta) in South America. Journal of Phycology, 2016, 52(2), 200-208. http://dx.doi.org/10.1111/jpy. 12382. PMid:27037585.

MORALES, E.A. Floración de Ceratium furcoides (Levander) Langhans (Dinoflagellata, Dinophyceae) en la represa de La Angostura, Cochabamba, Bolivia. Acta Nova, 2016, 7(4), 389-398.

MOREIRA, R.A., ROCHA, O., SANTOS, R.M., LAUDARES-SILVA, R., DIAS, E.S. and ESKINAZISANT'ANNA, E.M. First record of Ceratium furcoides (Dinophyta), an invasive species, in a temporary high-altitude lake in the Iron Quadrangle (MG, Southeast Brazil). Brazilian Journal of Biology = Revista Brasileira de Biologia, 2015, 75(1), 98-103. http://dx.doi.org/10.1590/1519-6984.08013.

NAPIÓRKOWSKA-KRZEBIETKE, A., DUNALSKA, J.A. and ZEBBEK, E. Taxa-specific eco-sensitivity in relation to phytoplankton bloom stability and ecologically relevant lake state. Acta Oecologica, 2017, 81, 10-21. http://dx.doi.org/10.1016/j. actao.2017.04.002.

NICHOLLS, W., KENNEDY, K.H. and HAMMETT, C. A fish-kill in Heart Lake, Ontario, associated with the collapse of a massive population of Ceratium hirundinelia (Dinophyceae). Freshwater Biology, 1980, 10(6), 553-561. http://dx.doi. org/10.1111/j.1365-2427.1980.tb01231.x.

NISHIMURA, P.Y., PÔMPEO, M. and MOSCHINICARLOS, V. Invasive dinoflagellate Ceratium furcoides (Levander) Langhans in two linked tropical reservoirs In: Pômpeo, M., Moschini-Carlos, V., Nishimura, P.Y., Silva, S.C. and Doval, J.C.L., eds. Ecologia de reservatórios e interfaces. São Paulo: Instituto de Biociências da Universidade de São Paulo, 2015, pp. 132-142.

OLIVEIRA, F.H.P.C., MACÊDO, I.M.E., MOREIRA, C.H.P., SHINOHARA, N.K.S., LIRA, O.O. and RAMALHO, W.P. Ocurrence of Ceratium furcoides (Levander) Langhans 1925 (Dinophyceae: Ceratiaceae) in two reservoirs of the Capibaribe 
watershed located in Semiarid region. Revista GEAMA, 2016, 6(1), 25-33.

OLIVEIRA, H.S.B., MOURA, A.D.N. and CORDEIRO-ARAÚJO, M.K. First record of Ceratium Schrank, 1973 (Dinophyceae: Ceratiaceae) in freshwater ecosystems in the semiarid region of Brazil. Check List, 2011, 7(5), 626-628. http://dx.doi. org/10.15560/7.5.626.

PADISÁK, J., CROSSETTI, L.O. and NASELLIFLORES, L. Use and misuse in the application of the phytoplankton functional classification: A critical review with updates. Hydrobiologia, 2009, 621(1), 1-19. http://dx.doi.org/10.1007/s10750008-9645-0.

PADISÁK, J., VASAS, G. and BORICS, G. Phycogeography of freshwater phytoplankton: traditional knowledge and new molecular tools. Hydrobiologia, 2016, 764(1), 3-27. http://dx.doi. org/10.1007/s10750-015-2259-4.

PAPA, R.D.S. and MAMARIL SR., A.C.. History of the biodiversity and limno-ecological studies on Lake Taal with notes on the current state of Philippine limnology. Philippine Science Letters, 2011, 4(1), $1-10$.

POPOVSKÝ, J. and PFIESTER, L.A. Dinophyceae (Dinoflagellida) In: Ettl, H., Gerloff, J. and Heynig, H., eds. Süssewasserflora von Mitteleurope, Vol. 6. Stuttgart: Gustav Fischer Verlag, 1990, pp. 1-272.

RAMÍREZ-R J.J., GUTIÉRREZ, F.L. and VARGAS, A. Respuesta de la Comunidad Fitoplanctónica a Experimentos de Eutrofización Artificial Realizados en la Represa La Fe, El Retiro, Antioquia, Colombia. Caldasia, 2005, 27(1), 103-115.

RAMOS, D.S. and CARNEIRO, V.A. Identificação de problemas ambientais em áreas de preservação permanente do córrego Capão Grosso em perímetro urbano de Caldas Novas (GO). Revista Percurso, 2010, 2(1), 135-154.

ROSINI, E.F., TUCCI, A., CARMO, C.F., ROJAS, N.E.T., BARROS, H.P. and MALLASEN, M. Changes in phytoplankton spatial and temporal dynamics in a Brazilian tropical oligotrophic reservoir after net cage installation. Brazilian Journal of Botany, 2016, 39(2), 569-581. http://dx.doi.org/10.1007/ s40415-016-0259-x.

ROTT, E., SILVA, E.I.L., ENRIQUEZ, E.E. and INGTHAMJITR, S. Phytoplankton community structure with special reference to species diversity in five tropical Asian water bodies. In: F. Schiemer, D. Simon, U. Amarasinghe and J. Moreau, eds. Aquatic ecosystems and development: comparative asian perspectives. Leiden: Backhuys Publishers, 2008, pp. 81-120.

SALUSSO, M.M. and MORAÑA, L.B. Fitoplancton de dos embalses de la Provincia de Salta. Lhawet, 2015, 4(1), 33-39.
SALUSSO, M.M. and MORAÑA, L.B. Fitoplancton de embalses subtropicales del noroeste argentino. Gestion y Ambiente, 2014, 17(1), 209-222.

SANTER, B. Nutritional suitability of the dinoflagellate Ceratium furcoides for four copepod species. Journal of Plankton Research, 1996, 18(3), 323-333. http:// dx.doi.org/10.1093/plankt/18.3.323.

SANTOS-WISNIEWSKI, M.J., SILVA, L.C., LEONE, I.C., LAUDARES-SILVA, R. and ROCHA, O. First record of the occurrence of Ceratium furcoides (Levander) Langhans 1925, an invasive species in the hydroelectricity power plant Furnas Reservoir, MG, Brazil. Brazilian Journal of Biology = Revista Brasileira de Biologia, 2007, 67(4), 791-793. http:// dx.doi.org/10.1590/S1519-69842007000400033. PMid: 18278340.

SILVA, C.A., TRAIN, S. and RODRIGUES, L.C. Estrutura e dinâmica da comunidade fitoplanctônica a jusante e montante do reservatório de Corumbá, Caldas Novas, Estado de Goiás, Brasil. Acta Scientiarum. Biological Sciences, 2001, 23(2), 283290.

SILVA, L.C., LEONE, I.C., SANTOS-WISNIEWSKI, M.J., PERET, A.C. and ROCHA, O. Invasion of the dinoflagellate Ceratium furcoides (Levander) Langhans 1925 at tropical reservoir and its relation to environmental variables. Biota Neotropica, 2012, 12(2), 93-100. http://dx.doi.org/10.1590/S167606032012000200010.

SIMMONDS, B., WOOD, S.A., ÖZKUNDAKCI, D. and HAMILTON, D.P. Phytoplankton succession and the formation of a deep chlorophyll maximum in a hypertrophic volcanic lake. Hydrobiologia, 2015, 745(1), 297-312. http://dx.doi.org/10.1007/s10750014-2114-z.

THOMASSON, K. Roturua phytoplankton reconsidered (North Island of New Zealand). Internationale Revue der Gesamten Hydrobiologie, 1974, 59(5), 703-727. http://dx.doi.org/10.1002/iroh.19740590509.

UTERMÖHL, H. Zur Vervollkommnung der quantitativen Phytoplankton-Methodik. Mitteilungen der Internationale Vereinigung für Theoretiche und Angewandte Limnologie, 1958, 9, 1-38.

VILLABONA-GONZÁLEZ, S.L., BUITRAGOAMARILES, R.F., RAMÍREZ-RESTREPO, J.J. and PALACIO-BAENA, J.A. Biomasa de rotíferos de dos embalses con diferentes estados tróficos (Antioquia, Colombia) y su relación con algunas variables limnológicas. Actualidades Biologicas, 2014, 36(101), 149-162.

WU, J. and CHOU, J.-W. Dinoflagellate associations in Feitsui Reservoir, Taiwan. Botanical Bulletin Academia Sinica Taipei, 1998, 39, 137-145.

Received: 11 May 2017 Accepted: 30 July 2018 